\title{
A Comparative Study of Cells and Mitochondria of Saccharomyces cerevisiae and of a Hydrocarbon-utilizing Yeast, Candida lipolytica
}

\author{
By M. D. SKIPTON, K. WATSON,* R. L. HOUGHTON \\ AND D. E. GRIFFITHS \\ Department of Molecular Sciences, University of Warwick, Coventry CV4 $7 A L$
}

(Received 7 February 1974; revised 25 April 1974)

\begin{abstract}
SUMMARY
The properties of cells and mitochondria isolated from Candida lipolytica, a hydrocarbon-utilizing yeast, grown on ethanol, glucose and $n$-alkanes were examined. A comparative study was made of the properties of the whole cells and mitochondria of C. lipolytica and of those of Saccharomyces cerevisiae.

The reduced-minus-oxidized cytochrome spectrum of $C$. lipolytica grown on ethanol showed a much larger amount of cytochromes $a a_{3}$ and a very broad cytochrome $b$-type absorption band compared with $S$. cerevisiae. The relative amounts of cytochromes in C. lipolytica on hydrocarbons differed according to the growth phase but never reached the levels observed in the cells grown on ethanol. Furthermore, as judged by the reduced-minus-oxidized cytochrome spectra, $C$. lipolytica was much less affected by glucose repression than was $S$. cerevisiae. The fatty acids of mitochondria isolated from ethanol-grown $C$. lipolytica consisted mainly of equal amounts of oleic $\left(\mathrm{C}_{18: 1}\right)$ and linoleic $\left(\mathrm{C}_{18: 2}\right)$ unsaturated fatty acids, each making up about $40 \%$ of the total. In contrast, $S$. cerevisiae mitochondria contained palmitoleic $\left(\mathrm{C}_{16: 1}\right)$ (approx. $45 \%$ ) and oleic (approx. $35 \%$ ) as the main fatty-acid components. There was an increase in the amount of oleic acid $(60 \%)$ relative to linoleic acid $(20 \%)$ when $C$. lipolytica was grown on even-numbered hydrocarbons and a progressive increase in the amount of heptadecenoic acid $\left(\mathrm{C}_{17: 1}\right)$ up to $75 \%$ when grown on odd-numbered $n$-alkanes of increasing carbonchain length from $C_{11}$ to $C_{15}$. The changes in fatty-acid composition were correlated with changes in membrane fluidity as measured by differences in transition temperatures in Arrhenius plots of mitochondrial membrane-bound enzymes.

The ATPases of C. lipolytica and S. cerevisiae mitochondria were examined, and marked differences in specific activity (3- to 5-fold higher in $S$. cerevisiae), $\mathrm{pH}$ profile and oligomycin sensitivity were noted.
\end{abstract}

\section{INTRODUCTION}

There has recently been much interest in micro-organisms, including yeasts, capable of utilizing hydrocarbons as sole carbon source. There are now several commercial operations for the production of yeast for the preparation of animal feedstuffs from waste paraffins obtained in the fractionation of crude oil (Wilkinson, I97I). The degradation of aliphatic hydrocarbons by micro-organisms has been discussed by Klug \& Markovetz (1970) and the breakdown of $n$-alkanes by yeast cells has recently been described (Gallo, Roche, Aubert \& Azoulay, 1973 $a$; Gallo, Bertrand, Roche \& Azoulay, 1973 b). The hydrocarbon is thought to proceed to the primary alcohol and then through the aldehyde to the fatty acid. It is presumed that it is then broken down in the mitochondria by $\beta$-oxidation.

\footnotetext{
* Present address: Department of Chemistry and Biochemistry, James Cook University of North Queensland, Townsville, Queensland 48I I, Australia.
} 
There have been few reports on the properties of mitochondria from hydrocarbonutilizing yeast. The present studies were undertaken to describe some of the properties of intact cells and mitochondria from $C$. lipolytica grown on different substrates which included $n$-alkanes of chain length $\mathrm{C}_{10}$ to $\mathrm{C}_{16}$. The properties of the cells and mitochondria of $C$. lipolytica were compared with those of $S$. cerevisiae. Marked differences in cytochrome content, fatty-acid composition and in the activities of mitochondrial membrane-bound enzymes were observed. Preliminary accounts of parts of this work have been reported (Skipton, Watson, Houghton \& Griffiths, 1973; Houghton, Skipton, Watson \& Griffiths, 1973).

\section{METHODS}

Growth of organisms. Candida lipolytica, strain YB423 (B.P. Chemicals, Sunbury-on-Thames, Middlesex), was grown in a fermenter (New Brunswick Scientific Co., New Brunswick, New Jersey, U.S.A.) at $30{ }^{\circ} \mathrm{C}$ in a medium containing (per litre): $0.5 \%(\mathrm{w} / \mathrm{v})$ yeast extract; $2.5 \mathrm{~g} \mathrm{NH} 4 \mathrm{Cl} ; 7.0 \mathrm{~g} \mathrm{KH}_{2} \mathrm{PO}_{4} ; 3.0 \mathrm{~g} \mathrm{Na}_{2} \mathrm{HPO}_{4} .2 \mathrm{H}_{2} \mathrm{O} ; 0.2 \mathrm{~g} \mathrm{MgSO}_{4} .7 \mathrm{H}_{2} \mathrm{O} ; 0 . \mathrm{I} \mathrm{g} \mathrm{NaCl}$; $0.5 \mathrm{mg} \mathrm{HBO}_{3} ; 0.4 \mathrm{mg} \mathrm{CuSO}_{4} .5 \mathrm{H}_{2} \mathrm{O} ; 0 . \mathrm{I} \mathrm{mg} \mathrm{KI} ; 0.4 \mathrm{mg} \mathrm{MnSO}_{4} ; 0.2 \mathrm{mg} \mathrm{Na} \mathrm{MoO}_{4} .2 \mathrm{H}_{2} \mathrm{O}$; $0.4 \mathrm{mg} \mathrm{ZnSO}_{4} .7 \mathrm{H}_{2} \mathrm{O} ; 0.2 \mathrm{mg} \mathrm{FeCl}_{3} . \mathrm{CaCl}_{2} .2 \mathrm{H}_{2} \mathrm{O}(0 . \mathrm{I} \mathrm{g})$ was added after autoclaving. Ethanol $(0.5 \%, \mathrm{v} / \mathrm{v})$, glucose $(5.0 \%, \mathrm{w} / \mathrm{v})$ or $n$-alkane $(0 . \mathrm{I}$ to $0.4 \%, \mathrm{v} / \mathrm{v})$ was used as carbon source as indicated in the text. Tributyl citrate at $0 . \mathrm{I}$ to $0.2 \mathrm{ml} / 1$ was used as antifoaming agent, and the $\mathrm{pH}$ of the medium was between $5 \cdot 8$ and $6 \cdot 0$. Stirring speed was $500 \mathrm{rev} . / \mathrm{min}$ and compressed air was passed through the culture at I 1 air $/ \mathrm{min} / 1$ medium. Saccharomyces cerevisiae, strain D22, was grown under the same conditions except that the mineral salts were according to Wickerham (1946) and adenine sulphate $(0 \cdot \mathrm{I} / \mathrm{l})$ was added to the medium. A $\mathrm{x} \cdot 0 \%$ inoculum from a starter culture grown for $24 \mathrm{~h}$ on $0.5 \%(\mathrm{v} / \mathrm{v})$ ethanol was used.

The yeasts were also grown on ethanol $(0.5 \%, \mathrm{v} / \mathrm{v})$ or glucose $(5.0 \%, \mathrm{w} / \mathrm{v})$ in 400 to $500 \mathrm{ml}$ medium in 21 conical flasks at $30^{\circ} \mathrm{C}$ and shaken at $250 \mathrm{rev} . / \mathrm{min}$ on a Mark 5 shaker (L.H. Engineering Co., Stoke Poges, Buckinghamshire). These cultures were normally used for cytochrome determinations as indicated in the text.

Isolation of mitochondria. Yeasts were harvested at exponential or early stationary phase as indicated in the text, washed, and then resuspended in buffer containing $0.5 \mathrm{M}$-sorbitol, $20 \mathrm{~mm}$-tris- $\mathrm{HCl}$, I mM-EDTA and bovine serum albumin (BSA) $(0.2 \%, \mathrm{w} / \mathrm{v})$ at $\mathrm{pH} 8 \cdot 0$. They were broken with glass beads $(0.45$ to $0.5 \mathrm{~mm}$ diam) for $15 \mathrm{~s}$ in a Braun shaker (B. Braun Apparatebau, Melsungen, Germany) at 4000 rev./min. Mitochondria were isolated from the homogenate by differential centrifugation and further purified on a discontinuous 20 to $70 \%(\mathrm{w} / \mathrm{v})$ sucrose gradient containing $20 \mathrm{~mm}$-tris-HCl, I mM-EDTA pH $7 \cdot 5$. Gradients were run at $24000 \mathrm{rev}$./min for $2.5 \mathrm{~h}$ in the SW 25. I rotor of a Beckman Model L2 ultracentrifuge. The main mitochondrial band was collected and resuspended in buffer containing $0.25 \mathrm{M}$-sorbitol, $20 \mathrm{~mm}$-tris- $\mathrm{HCl}$, I mM-EDTA pH 7.5 at a protein concentration of approximately $15 \mathrm{mg} / \mathrm{ml}$. Mitochondria were also prepared by digestion of the yeast wall with snail-gut enzymes and disruption of the protoplasts in a French pressure cell, as previously described (Watson, Haslam \& Linnane, 1970).

Estimation of fatty acids. Harvested, washed yeast ( $1 \cdot 0$ to $2 \cdot 0 \mathrm{~g}$ wet wt) or 20 to $40 \mathrm{mg}$ mitochondria were resuspended in 3 to $5 \mathrm{ml}$ of $40 \%(\mathrm{w} / \mathrm{v})$ potassium hydroxide and refluxed for $4 \mathrm{~h}$ to saponify the lipids. Fatty-acid esters were prepared and determined by gas-liquid chromatography on a polyethyleneglycol succinate column as previously described (Watson, Bertoli \& Griffiths, 1973a). Relative percentages of fatty acids were 
determined by measurement of the peak areas, estimated from peak height $\times$ one-half peak base.

Cytochrome spectra. The spectra were recorded on a Unicam SPI 800 spectrophotometer in I cm light path cells (final volume 2.5 to $3.0 \mathrm{ml}$ ) using the turbid solution cell position and a slit width of $0.6 \mathrm{~mm}$. The sample cell was reduced with a few grains of dithionite and the reference cell was oxidized with $10 \mu \mathrm{l}$ of $100 \mathrm{vol} . \mathrm{H}_{2} \mathrm{O}_{2}$. Difference spectra of mitochondria were recorded under the same conditions.

Succinate oxidase and NADH oxidase assays. Oxygen uptake was measured by means of a thermostatted oxygen electrode. Two $\mathrm{ml}$ of air-equilibrated buffer containing $50 \mathrm{~mm}-$ potassium phosphate $\mathrm{pH} 7 \cdot 4$ was used for each assay; 50 to $200 \mu 1$ of mitochondrial suspension ( 0.5 to I. $5 \mathrm{mg}$ protein) was added and, after a further minute, $0.4 \mathrm{mM}$-ADP followed by either NADH $(2.5 \mathrm{~mm})$ or succinate $(20 \mathrm{~mm})$ as substrate.

Succinate dehydrogenase assay. A Cary I4 spectrophotometer fitted with a Churchill refrigerated thermostat was used to assay the enzyme. Accurate temperature measurement was by means of a thermocouple $\left( \pm 0 \cdot I^{\circ} \mathrm{C}\right)$ which fitted directly into the cuvette $(\mathrm{I} \cdot 0 \mathrm{~cm}$ light path). The reaction mixture contained, in a final volume of $\mathrm{I} \cdot \mathrm{I} \mathrm{ml}, 50 \mathrm{~mm}$-potassium phosphate, 50 to I00 $\mu \mathrm{g}$ mitochondrial protein, $25 \mathrm{~mm}$-succinate and $2 \mathrm{~mm}-\mathrm{KCN}, \mathrm{pH} 7 \cdot 4$. Incubation was for $5 \mathrm{~min}$ and then the reaction was started by the rapid addition of $0.05 \mathrm{mM}$ 2,6-dichlorophenol-indophenol (DCPIP) and $0.5 \mathrm{mM}$-phenazine methosulphate (PMS). The decrease in absorbance of DCPIP at $600 \mathrm{~nm}$ was followed. An extinction coefficient of $e_{\mathrm{mm}}=2 \mathrm{I}$ was used (King \& Howard, 1967). A current of dry nitrogen was passed through the cell chamber to prevent condensation at the lower temperatures.

Mitochondrial ATPase assay. The ATPase was assayed at $30{ }^{\circ} \mathrm{C}$ as previously described (Houghton et al. 1973).

Dry weight and protein estimations. Dry weights of intact yeasts were measured after filtration on to Whatman GF/C glass-fibre paper $(2.4 \mathrm{~cm}$ diam) and drying in an oven at I IO to I $20{ }^{\circ} \mathrm{C}$ for $24 \mathrm{~h}$. Protein estimations were by the procedure of Lowry, Rosebrough, Farr \& Randall (I95I).

Materials. ADP, ATP, PMS, DCPIP, NADH and oligomycin were obtained from Sigma. Methyl ester standards of fatty acids were obtained from Sigma or from BDH. All other chemicals were of analytical reagent grade where available.

\section{RESULTS}

As shown in Fig. I the growth curves of Candida lipolytica and Saccharomyces cerevisiae on ethanol were essentially the same. The lag phase of about to h may be contrasted with the much longer lag phase of about $\mathrm{I} 8 \mathrm{~h}$ when $C$. lipolytica was grown on tetradecane.

Candida lipolytica can utilize hydrocarbon as sole carbon source and is able to grow in liquid culture on $n$-alkanes of 10 to 20 carbon atoms in chain length. Most of the studies on the growth of yeast on hydrocarbons, in order to determine substrate specificity, have been done using Candida species. Differences in cell yield on $n$-alkanes of varying chain length do not follow any general rule (Klug \& Markovetz, 1970). In the measurements of growth of $C$. lipolytica on several $n$-alkanes in batch culture (Fig. 2) it was noticeable that there was no large increase in cell yield in going from $n$-decane to $n$-tetradecane and $n$-hexadecane. Furthermore, when the concentration of $n$-tetradecane was increased fourfold there was less than a twofold increase in the cell yield (Fig. 2). These results may be contrasted with those for cells grown on ethanol where there was an approximate doubling in yield in going from 0.5 to $\mathrm{I} \cdot 0 \%(\mathrm{v} / \mathrm{v})$ ethanol (results not shown). 


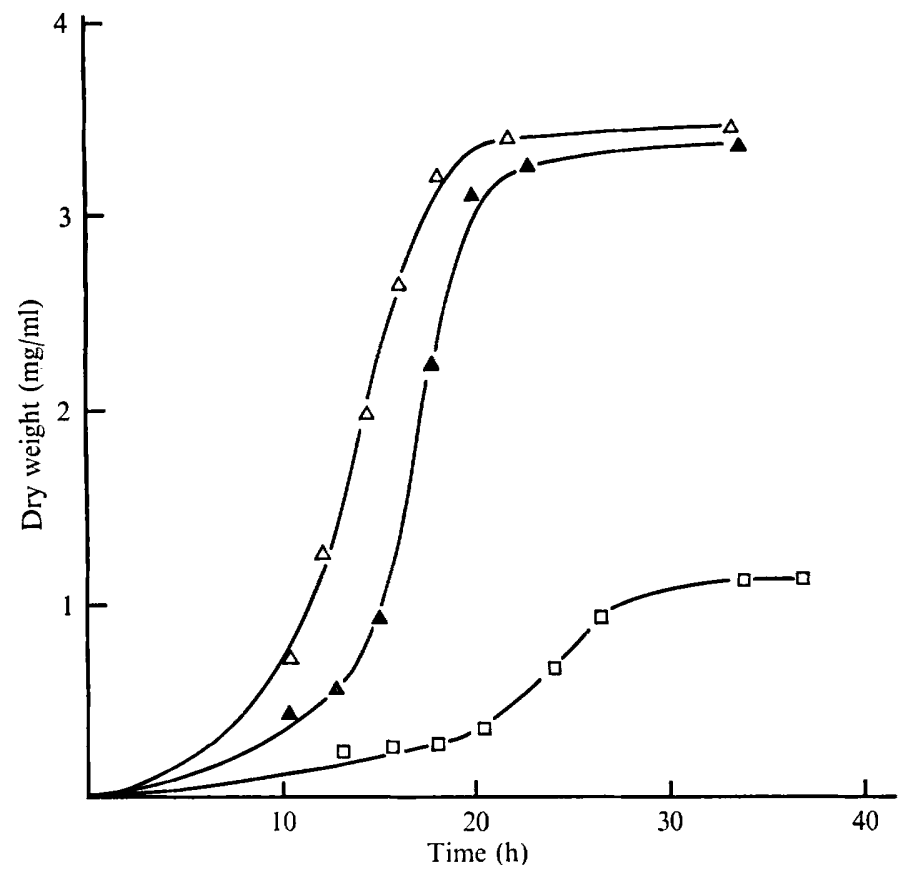

Fig. I. Growth curves of $S$. cerevisiae and $C$. lipolytica in fermenters. $\triangle, S$. cerevisiae and, $\Delta$, C. lipolytica grown on ethanol $(0.5 \%, \mathrm{v} / \mathrm{v}) . \square, C$. lipolytica grown on $n$-tetradecane $(0 . \mathrm{I} \%, \mathrm{v} / \mathrm{v})$.

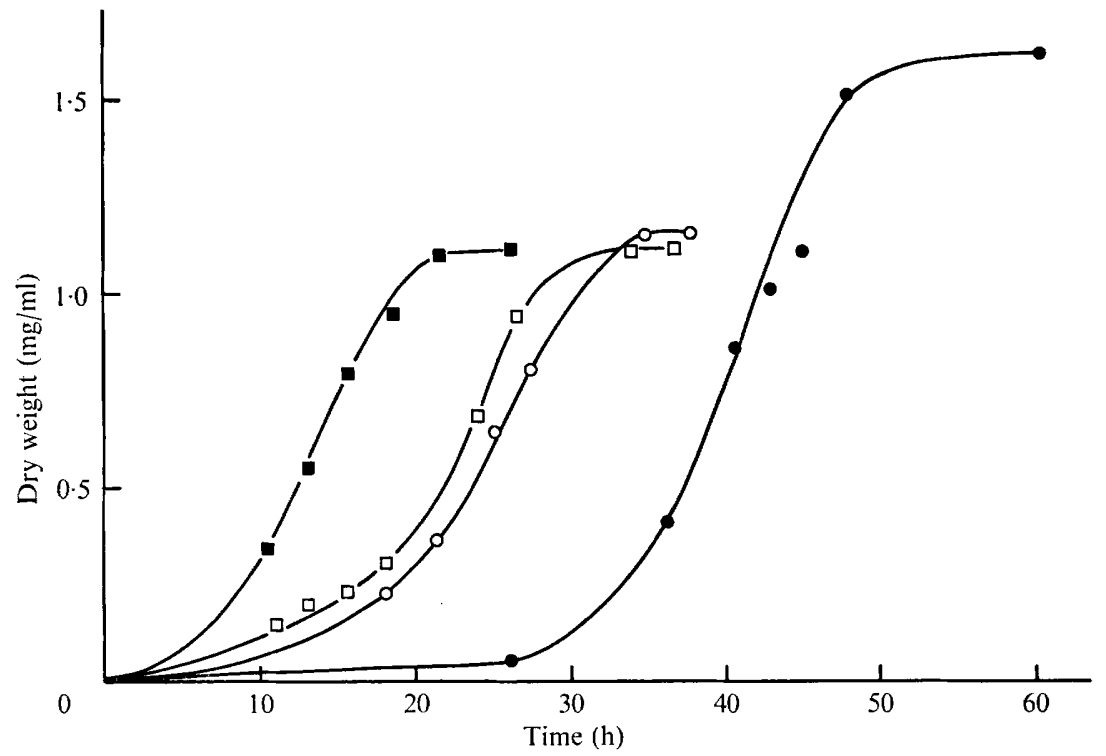

Fig. 2. Growth curves of $C$. lipolytica on various $n$-alkanes. $\square$, Decane $(0 \cdot I \%, v / v) ; \square$, tetradecane $(0.1 \%, v / v) ; 0$, hexadecane $(0.1 \%, v / v) ; 0$, tetradecane $(0.4 \%, v / v)$.

There are two basic ways in which uptake of hydrocarbons by yeast cells can occur. This may be either by direct contact of the cells with paraffin droplets or by transfer from the droplets to the cells through the aqueous phase. Evidence for the former mechanism has been presented by several authors (see Klug \& Markovetz, I970). On the other hand, 
Table I. Fatty-acid composition of intact yeast cells grown on different carbon sources

Total

unsaturated

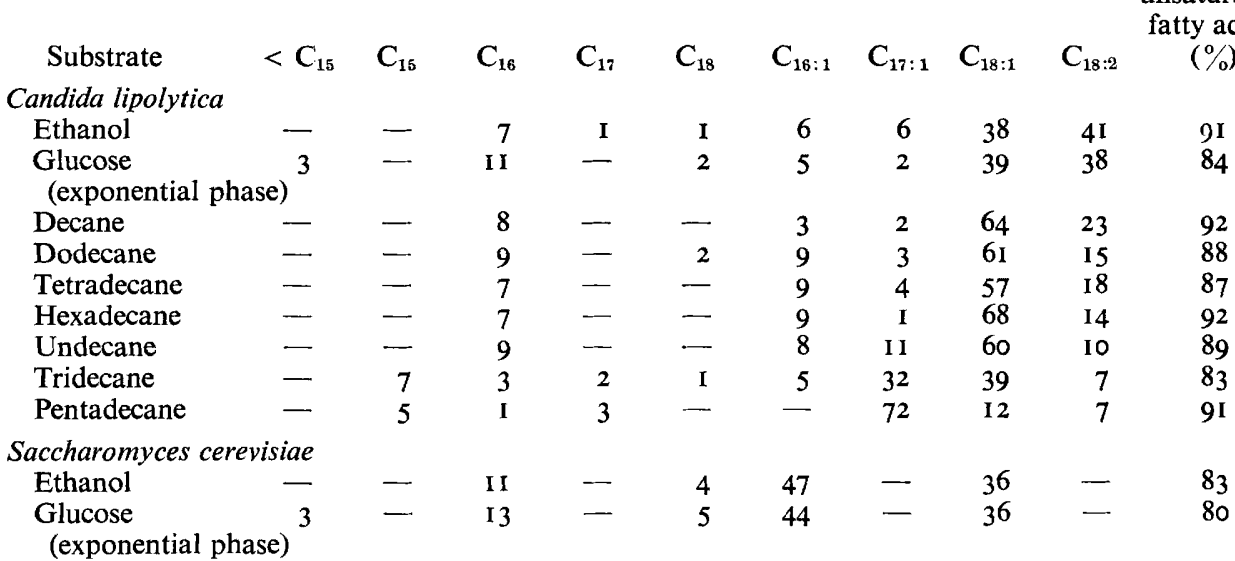

Fatty acids are shown as percentages of total fatty acids and denoted by the convention, number of carbon atoms: number of double bonds. All cells were harvested at stationary phase unless otherwise shown.

Goma, Pareilleux \& Durand (I973) have recently shown that the most soluble $n$-alkane, present either as the sole carbon source or in a mixture of 2 or $8 n$-alkanes, was always the first to be utilized. In the present studies, it was observed that $n$-decane was taken up much more rapidly than $n$-tetradecane or $n$-hexadecane (Fig. 2). These results could be interpreted as indicating that the hydrocarbons were utilized primarily in the dissolved state, since the solubility of $n$-decane in aqueous solution is much greater than that of the other hydrocarbon substrates (McAuliffe, 1969). However, when the concentration of the hydrocarbon substrate was increased, the lag phase of growth was also prolonged (Fig. 2). It is clear, therefore, that other factors such as the physical state of the hydrocarbon droplets have to be taken into consideration in proposing a mechanism for hydrocarbon uptake by yeast (Moo-Young, Shimizu \& Whitworth, I97I). It is possible that hydrocarbon utilization may proceed by both mechanisms, i.e. in the dissolved state and also by direct contact, the exact mechanism depending on such parameters as physical state of the hydrocarbon substrate, phase of growth, temperature, etc.

\section{Cell fatty acids}

Under all conditions of growth on ethanol, glucose or $n$-alkane as substrate the $C$. lipolytica cells contained between 80 and $90 \%$ of the total fatty acid as unsaturated fatty acid (Table I). The major components were oleic $\left(C_{18: 1}\right)$ and linoleic $\left(C_{18: 2}\right)$ unsaturated fatty acids when $C$. lipolytica was grown on ethanol, glucose or even-numbered $n$-alkanes. There were, however, significant differences in the relative amounts of oleic and linoleic fatty acids depending on the nature of the substrate. When $C$. lipolytica was grown on ethanol or glucose, the ratio of oleic to linoleic was about I:I and these made up approximately $80 \%$ of the total fatty acids, with small amounts of palmitic and palmitoleic acids and traces of heptadecenoic and stearic acids accounting for the rest. In Candida grown on even-numbered $n$-alkanes from decane to hexadecane the ratio of oleic to linoleic was in all cases about $3:$ I. These were again the major fatty-acid constituents $(80 \%$ of the total) with small amounts of palmitic, palmitoleic, heptadecenoic and stearic acids account- 
Table 2. Fatty-acid composition of mitochondria isolated from Saccharomyces cerevisiae and Candida lipolytica



Fatty acids are shown as percentages of total fatty acids and denoted by the convention, number of carbon atoms: number of double bonds.

ing for the rest. There were no significant changes in the cell fatty-acid profiles of $C$. lipolytica at different growth phases in batch culture on ethanol or hydrocarbons under our conditions of growth. Candida lipolytica grown on odd-numbered $n$-alkanes showed an increasing incorporation (from II \% of the total to $72 \%$ ) of heptadecenoic acid $\left(\mathrm{C}_{17: 1}\right)$ in going from undecane to tridecane to pentadecane, with a corresponding decrease in the amounts of oleic and linoleic acids (Table 1). It was possible to demonstrate a linear relationship between the relative amount of fatty acids with eighteen carbon atoms after, growth on odd-numbered $n$-alkanes, and the number of carbon atoms in the hydrocarbon chain, i.e. in going from $C_{11}$ to $C_{13}$ to $C_{15}$, the $C_{18}$ fatty acids made up 70,47 and $19 \%$, respectively, of the total fatty acids. Hug \& Fiechter (I973) have also shown a similar relationship in Candida tropicalis grown on $n$-alkanes. The biosynthesis of $\mathrm{C}_{18}$ fatty acids, at least in the case of Candida sp. grown on odd-numbered $n$-alkanes, therefore appears to be dependent on the chain length of the $n$-alkane substrate.

Table I summarizes the fatty-acid composition of $C$. lipolytica grown on different substrates. For comparison we have included the fatty-acid profile of $S$. cerevisiae grown on ethanol and on glucose. In contrast to $C$. lipolytica cells, those of $S$. cerevisiae were extremely rich in palmitoleic acid $\left(\mathrm{C}_{16: 1}\right)$, which accounted for about $45 \%$ of the total cell fatty acid, with oleic acid $\left(\mathrm{C}_{18: 1}\right)$ accounting for about $35 \%$.

\section{Mitochondrial fatty acids}

The fatty-acid composition of $C$. lipolytica mitochondria (Table 2) was similar to that of the corresponding intact cells. Large amounts of heptadecenoic acid $\left(\mathrm{C}_{17: 1}\right)$ were present in the mitochondrial membranes of pentadecane-grown $C$. lipolytica cells.

The marked differences in the fatty-acid composition of $S$. cerevisiae and $C$. lipolytica mitochondria raised the possibility of differences in biochemical properties of the mitochondria from the two species of yeast. While the biochemical properties of $S$. cerevisiae mitochondria are well documented (Ohnishi et al. 1967; Kovac, Bednarova \& Greksak, I968; Mackler \& Haynes, 1973) there have been few reports on C. lipolytica mitochondria, particularly from cells grown on hydrocarbons. 




Fig. 3. Arrhenius plots of membrane-bound respiratory enzymes of mitochondria isolated from cells grown on ethanol. The specific activities were expressed as nmol substrate $/ \mathrm{min} / \mathrm{mg}$ protein for NADH oxidase and succinate oxidase, and as nmol DCPIP/min/mg protein for succinate dehydrogenase. Candida lipolytica: $O, \mathrm{NADH}$ oxidase; $\triangle$, succinate oxidase; $\square$, succinate dehydrogenase. Saccharomyces cerevisiae: $\bullet$, NADH oxidase; $\Delta$, succinate oxidase; $\mathbf{\square}$, succinate dehydrogenase.

\section{Arrhenius plots}

The effect of temperature on the activities of C. lipolytica and S. cerevisiae mitochondrial membrane-bound enzymes was examined. These studies were prompted by the differences in fatty-acid composition in the two mitochondrial species and by previous observations which showed that phase-transition temperatures in S. cerevisiae mitochondria are influenced by the fatty-acid composition of the membrane lipids (Ainsworth, Tustanoff \& Ball, 1972; Watson et al. 1973 a).

Figure 3 shows Arrhenius plots of the logarithms of specific activities plotted against the reciprocal of the absolute temperature for NADH and succinate oxidases of mitochondria isolated from ethanol-grown cells. In $C$. lipolytica mitochondria the phase-transition temperatures at which there was an increase in activation energy were in the range 14 to $17{ }^{\circ} \mathrm{C}$. By comparison the corresponding mitochondrial membrane-bound enzymes of $S$. cerevisiae showed transition temperatures in the range 17 to $20^{\circ} \mathrm{C}$. These differences in transition temperatures were observed over 4 or 5 separate mitochondrial preparations for both yeast 
Table 3. Transition temperatures and activation energies of Candida lipolytica and Saccharomyces cerevisiae mitochondrial membrane-bound enzymes

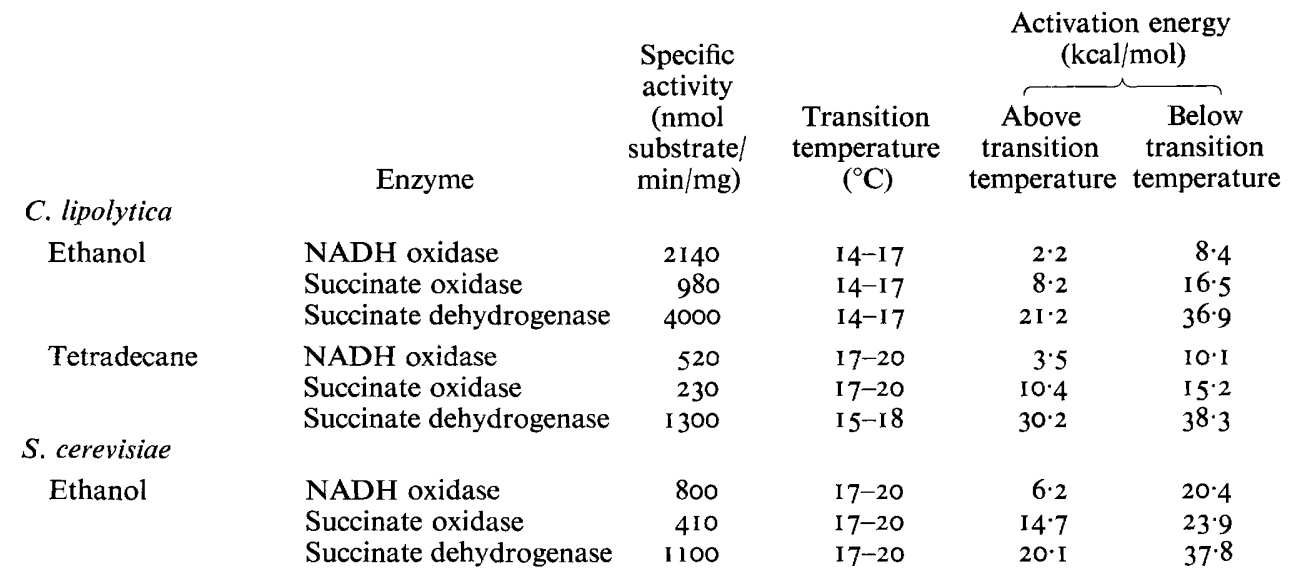

species. In general there was a two- to threefold increase in activation energy below the transition temperature (Table 3). Also, the specific activities of the NADH and succinate oxidases in $C$. lipolytica mitochondria were several-fold higher than those of the $S$. cerevisiae mitochondria (Table 3). A general characteristic of mitochondria from both yeast species was the lower activation energy, especially above the transition temperature, of the NADH oxidase as compared with the succinate oxidase system. As a result the NADH oxidase was still relatively active at temperatures well below the transition temperature (Fig. 3). By comparison, the succinate oxidase activity decreased rapidly at temperatures below the transition point (Fig. 3). A preliminary account of the lower activation energy of the NADH oxidase system has been presented (Watson, Bertoli \& Griffiths, 1973b).

Succinate dehydrogenase showed a similar non-intersecting discontinuity in Arrhenius plots (Fig. 3). Here again the specific activity of the C. lipolytica mitochondria was severalfold higher than the $S$. cerevisiae mitochondria. The activation energies, both above and below the transition temperatures, for both types of mitochondria, were similar (Table 3 ).

Arrhenius plots of the corresponding respiratory enzymes in mitochondria isolated from C. lipolytica grown on tetradecane are shown in Fig. 4. All three mitochondrial membranebound enzymes had lower specific activities and higher transition temperatures than those from mitochondria isolated from $C$. lipolytica grown on ethanol. The mitochondria from the tetradecane-grown cells were comparable in terms of specific activity to those of $S$. cerevisiae mitochondria. The transition temperatures were also in the same range (Table 3 ). The activation energies of the mitochondrial enzymes, above and below the transition temperatures, increased in the order NADH oxidase, succinate oxidase, succinate dehydrogenase, as they do in mitochondria isolated from ethanol-grown cells (Table 3 ). The activation energy of the succinate dehydrogenase of mitochondria isolated from tetradecanegrown cells was extremely high. However, it was not clear whether this observation was due to an artefact of the isolation procedure, since mitochondria from tetradecane-grown cells were prepared only by the mechanical-breakage procedure. 


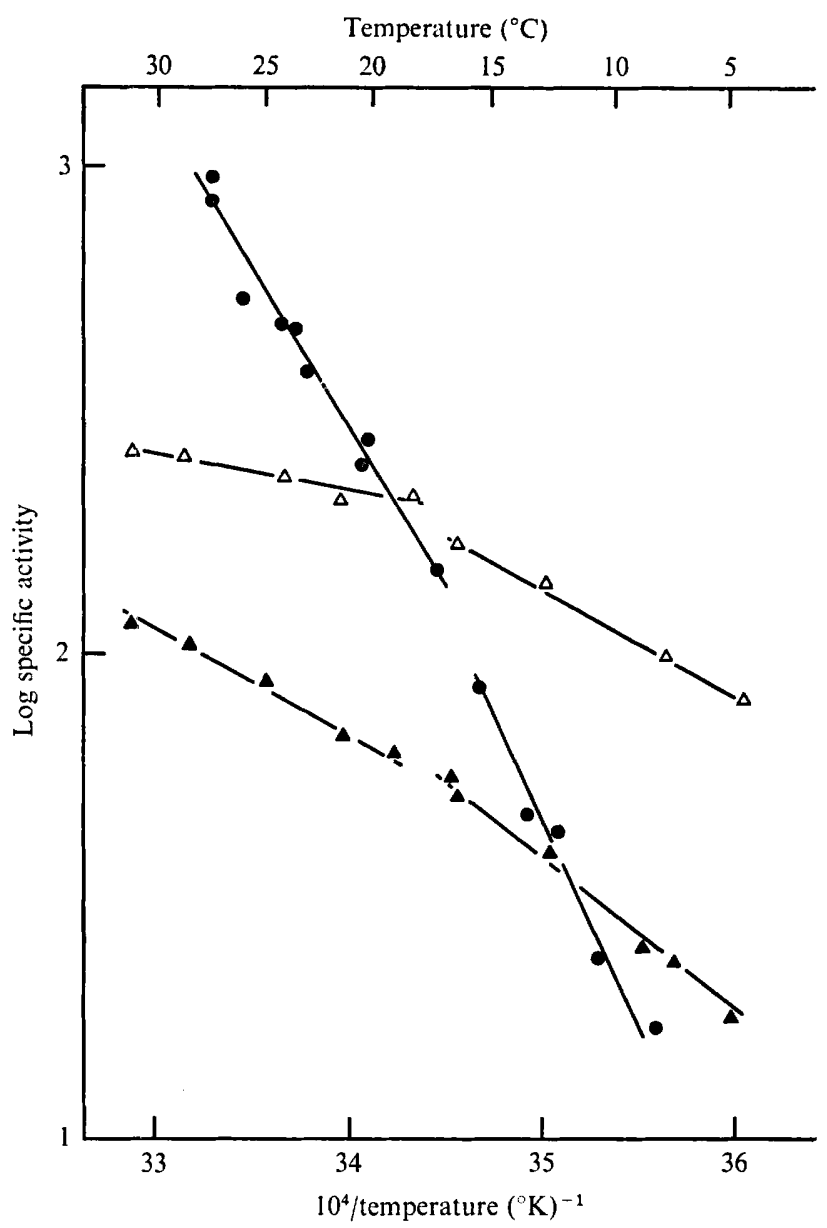

Fig. 4. Arrhenius plots of membrane-bound respiratory enzymes of mitochondria isolated from C. lipolytica cells grown on tetradecane. Specific activities were expressed as $\mathrm{nmol} / \mathrm{min} / \mathrm{mg}$ protein. $\triangle$, NADH oxidase; $\boldsymbol{\Delta}$, succinate oxidase; $\bullet$, succinate dehydrogenase.

\section{Cytochrome spectra}

The reduced-minus-oxidized cytochrome spectra of $C$. lipolytica and $S$. cerevisiae cells grown on ethanol in shake culture are shown in Fig. 5. The $C$. lipolytica cells were characterized by a large cytochrome $a a_{3}$ absorption peak at $605 \mathrm{~nm}$ and a relatively broad cytochrome $b$-type absorption in the 560 to $565 \mathrm{~nm}$ region. The differences in the cytochrome pattern of $C$. lipolytica compared with $S$. cerevisiae were further emphasized when the Soret bands were examined. In Candida cells there was a large absorption maximum at $445 \mathrm{~nm}$ characteristic of cytochromes $a a_{3}$, and a small shoulder in the 415 to $430 \mathrm{~nm}$ region due to reduced cytochrome $c(415 \mathrm{~nm})$ and cytochrome $b(425 \mathrm{~nm})$. Saccharomyces cells in contrast showed a peak in the Soret region at $445 \mathrm{~nm}$ characteristic of cytochromes $a a_{3}$ and a somewhat larger and broader absorption in the region $4 \mathrm{I} 5$ to $430 \mathrm{~nm}$, indicating a large amount of cytochrome $c$ relative to cytochromes $b$ and $a a_{3}$.

The cytochrome spectra of $C$. lipolytica grown on high glucose concentrations were examined, since under this condition $S$. cerevisiae shows a highly repressed cytochrome 


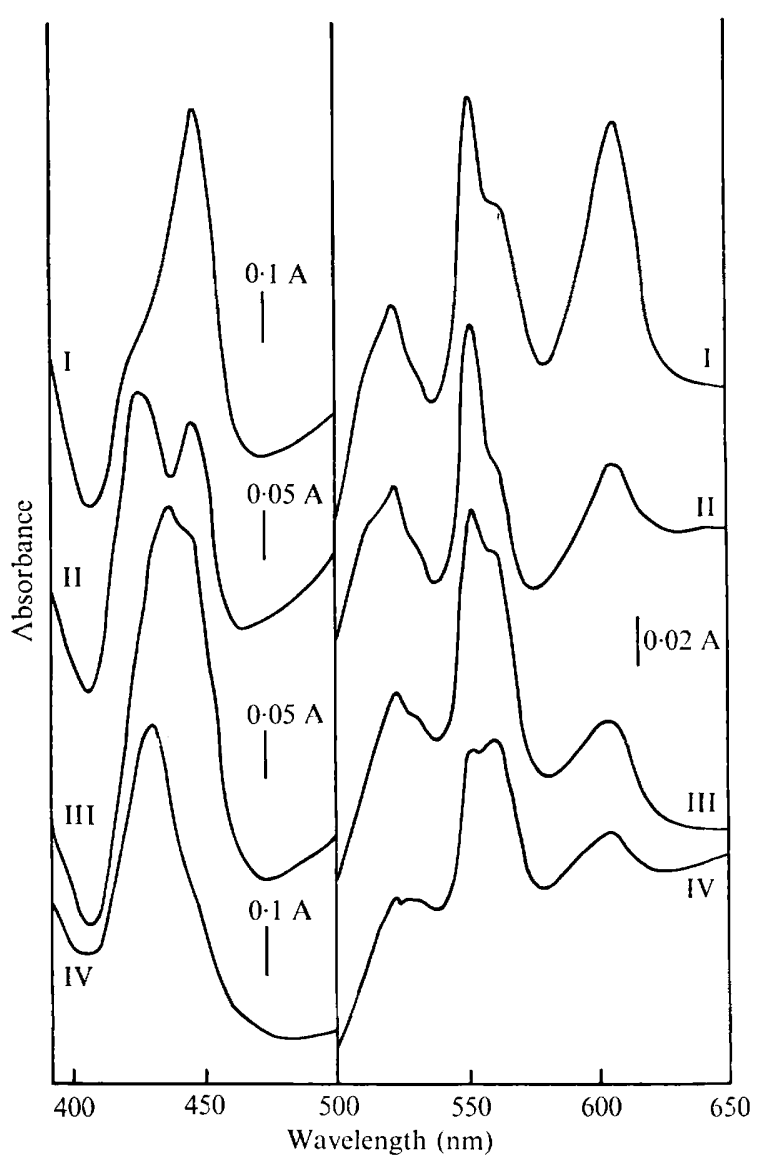

Fig. 5. Cytochrome reduced-minus-oxidized spectra of $C$. lipolytica and $S$. cerevisiae grown in shake culture on ethanol $(0.5 \%, \mathrm{v} / \mathrm{v})$ to early stationary phase, and of $C$. lipolytica grown on $n$-tetradecane $(0.2 \%, \mathrm{v} / \mathrm{v})$ fermenter. I, C. lipolytica on ethanol $(25 \mathrm{mg}$ dry wt $/ \mathrm{ml}) ; \mathrm{II}, S$. cerevisiae on ethanol (3I $\mathrm{mg}$ dry wt $/ \mathrm{ml}$ ); III, C. lipolytica on $n$-tetradecane (stationary phase, $28.5 \mathrm{mg}$ dry wt $/ \mathrm{ml}$ ); IV, C. lipolytica on $n$-tetradecane (log phase, $205 \mathrm{mg}$ dry $\mathrm{wt} / \mathrm{ml}$ ).

spectrum (Jayaraman, Cotman, Mahler \& Sharp, 1966). The cytochrome spectra of Candida and Saccharomyces cells grown on $5 \%(\mathrm{w} / \mathrm{v})$ glucose and harvested in the exponential phase are shown in Fig. 6. Saccharomyces cerevisiae showed a glucose-repressed cytochrome spectrum while C. lipolytica showed a spectrum more typical of derepressed cells (cf. Fig. 5). Although, on a cell dry weight basis, there were less cytochromes in the glucose-grown as compared with the ethanol-grown Candida cells, the $C$. lipolytica cells were obviously less subject to glucose repression than $S$. cerevisiae. Indeed the cytochrome content (again on a cell dry weight basis) of $C$. lipolytica grown on glucose compared favourably with that of fully derepressed $S$. cerevisiae grown on ethanol (cf. Table 4). The cytochrome $a a_{3}$ content of glucose- and ethanol-grown $C$. lipolytica cells was about five- and tenfold respectively higher than that of $S$. cerevisiae grown on ethanol.

Quite different cytochrome patterns were observed when $C$. lipolytica cells were grown on tetradecane. Figure 5 shows the reduced-minus-oxidized cytochrome spectra of tetradecanegrown cells harvested in exponential and stationary phases. The cytochrome spectra were 


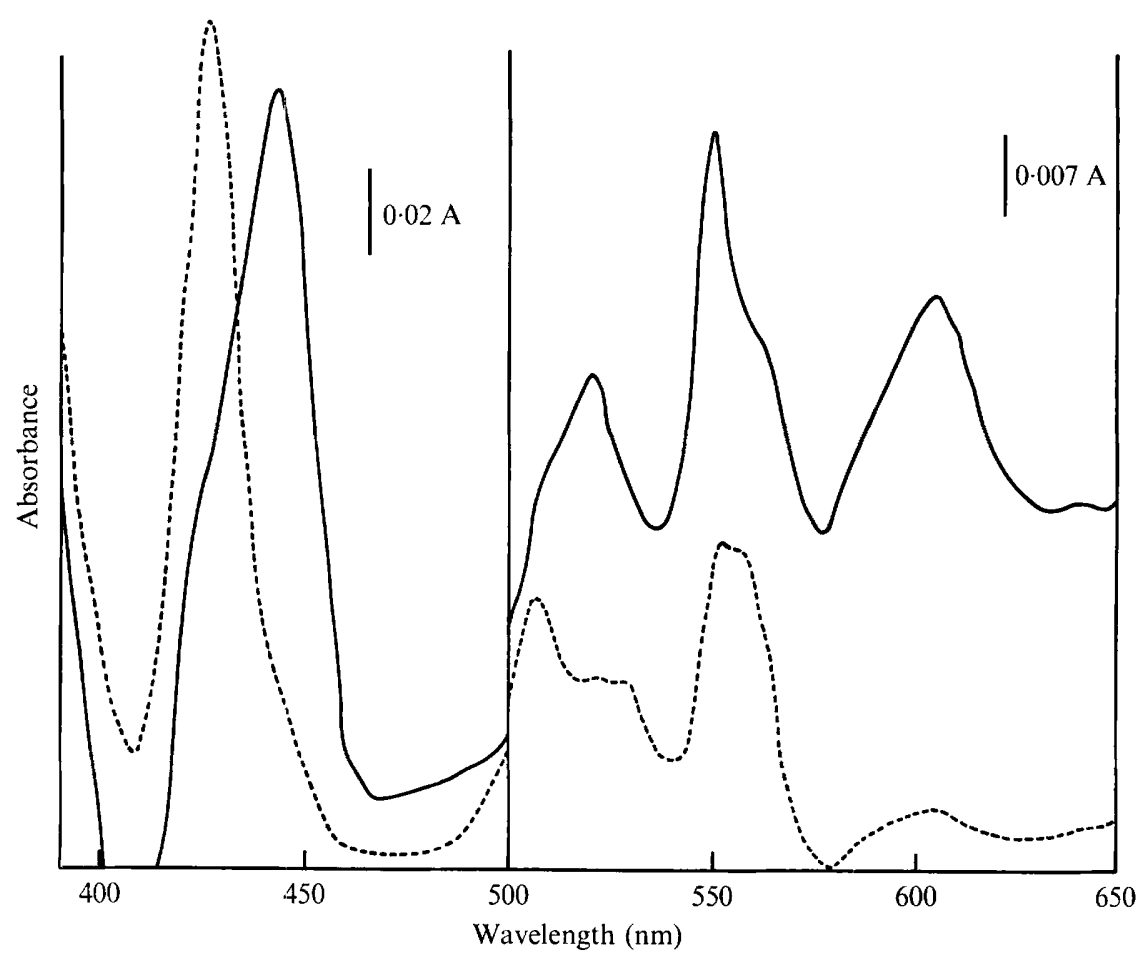

Fig. 6. Cytochrome reduced-minus-oxidized difference spectra of cells grown on glucose $(5 \cdot 0 \%$, w/v) in shake culture and harvested in exponential phase. Spectra were recorded as outlined in Methods. $\ldots$, C. lipolytica $(9 \mathrm{mg}$ dry $\mathrm{wt} / \mathrm{ml}) ; \ldots \ldots, S$. cerevisiae $(26 \mathrm{mg}$ dry wt/ml).

typical of the change in going from a repressed (exponential phase) to a derepressed (stationary phase) state characteristic of glucose derepression in $S$. cerevisiae (Slonimski, 1953; Jayaraman et al. 1966). The changes in the cytochrome spectra in the Soret region were particularly dramatic. In the case of the exponential phase cells, the cytochromes $a a_{3}$ absorption peak $(445 \mathrm{~nm})$ appeared as a small shoulder on the large cytochrome $b$ peak at $424 \mathrm{~nm}$ while in stationary phase the cytochromes $a a_{3}$ maximum was almost equal to the cytochrome $b$ absorption.

\section{Mitochondria}

It was not possible, from small-scale shake cultures, to obtain sufficient mitochondria for all the biochemical studies. The majority of experiments, therefore, were conducted on mitochondria isolated from yeasts grown in large-scale fermenters (see Methods). The cytochrome content of fermenter-grown yeast was somewhat less than that of yeast grown in small-scale shake culture (cf. Table 4). However, the same general trends in cytochrome composition were observed.

Quantitative estimation of the cytochrome content of the isolated mitochondria was complicated by the variable loss of cytochrome $c$ during the isolation procedures. This loss was apparent in mitochondria prepared both from mechanical disruption of cells and from protoplast lysates. Despite these difficulties it was still clear that mitochondria from C. lipolytica grown on ethanol had a much higher total cytochrome content than the corresponding mitochondria from $S$. cerevisiae. In particular the cytochromes $b$ and $a a_{3}$ contents 
Table 4. Cytochrome content of intact cells and mitochondria of Candida lipolytica and Saccharomyces cerevisiae grown on different substrates

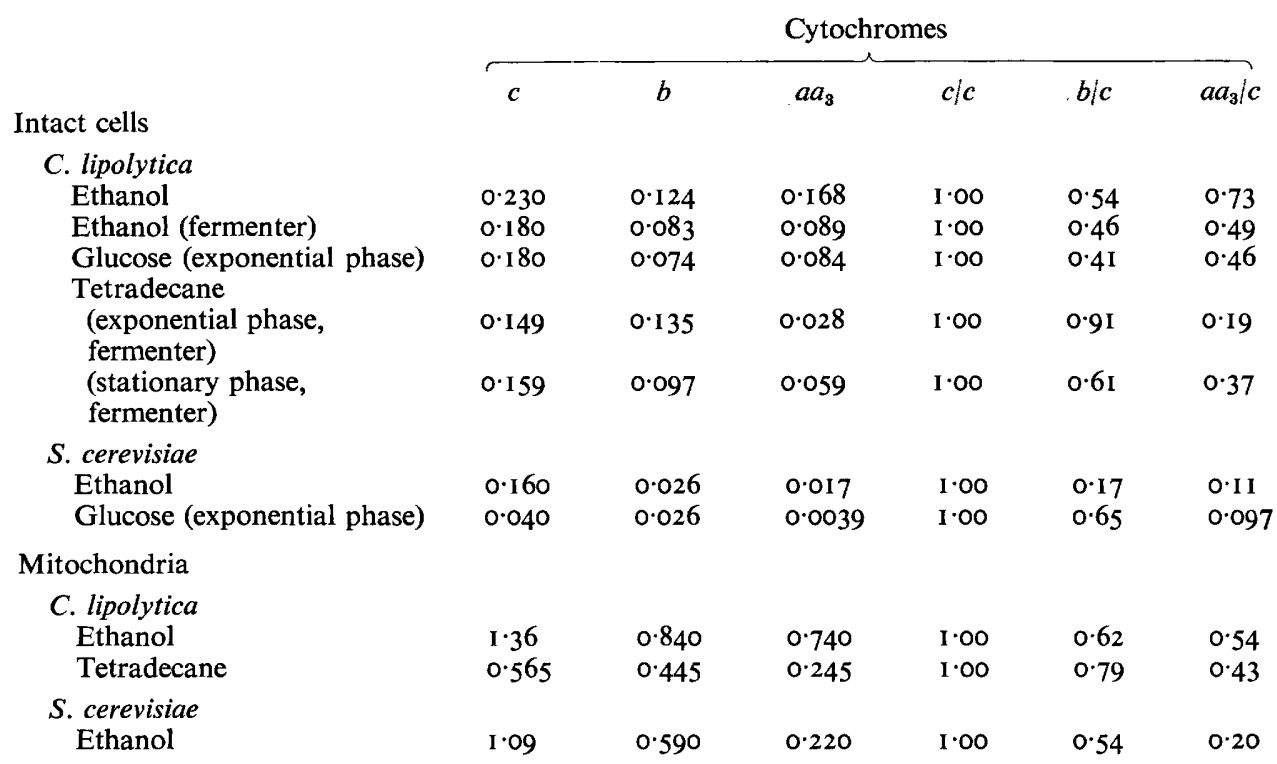

Cytochrome content of intact cells is shown as nmol $/ \mathrm{mg}$ dry weight. Cytochrome content of mitochondria is shown as $\mathrm{nmol} / \mathrm{mg}$ protein. The following extinction coefficients for cytochrome difference spectra were taken: cytochrome $c 550-540 \mathrm{~nm}, \epsilon_{\mathrm{mx}}=19$ (Wilson \& Epel, 1968); cytochrome $b 560-540 \mathrm{~nm}$ (Wilson \& Epel, 1968), $\epsilon_{\mathrm{mM}}=22$; cytochrome $a a_{3} 605-630 \mathrm{~nm}, \epsilon_{\mathrm{mM}}=24$ (van Gelder, I966).

Cells were grown in shake flasks $(2 \mathrm{l})$ and harvested in stationary phase unless otherwise indicated, washed in distilled water and resuspended in $60 \%$ (w/v) sorbitol, $50 \mathrm{~mm}$-phosphate, $\mathrm{pH} 7.0$ (I 5-25 $\mathrm{mg} \mathrm{dry} \mathrm{wt} / \mathrm{ml}$ ).

Mitochondria were isolated from stationary-phase cells grown in fermenters, and suspended in $0.25 \mathrm{M}-$ sorbitol, $20 \mathrm{~mm}$-tris- $\mathrm{HCl}$, I mM-EDTA, $\mathrm{pH} \mathrm{7 \cdot 5}$, to $4 \mathrm{mg}$ protein $/ \mathrm{ml}$.

of $C$. lipolytica were about $\mathrm{I} \cdot 5$ and 3.5 times higher, respectively, than those of $S$. cerevisiae. The cytochrome levels in $S$. cerevisiae presented in Table 4 were comparable to those reported by Ohnishi et al. (I967) for Saccharomyces carlsbergensis mitochondria.

A comparison of the ratios of cytochromes in S. cerevisiae and C. lipolytica is summarized in Table 4. For cells grown on ethanol the ratio of cytochrome $c: b: a a_{3}$ in $C$. lipolytica was I $\cdot 0: 0.54: 0.73$ and in $S$. cerevisiae I.0:0.17:0.II. These results clearly demonstrate that the $C$. lipolytica cells were comparatively rich in cytochromes $b$ and $a a_{3}$, and the $S$. cerevisiae cells in cytochrome $c$. The corresponding ratios for cells grown on glucose indicated that while there was some repression of cytochromes $b$ and $a a_{3}$ in $C$. lipolytica, the $S$. cerevisiae cells were relatively rich in cytochrome $b$ (cytochrome $c: b$ ratio of $1 \cdot 0: 0.65$ ); the cytochrome $c: a a_{3}$ ratio of $\mathrm{I} \cdot 0: 0 \cdot 10$ was about the same as that of the ethanol-grown cells. In $S$. cerevisiae the amount of cytochrome $b$, at least on a dry weight basis, was the same in ethanol-grown and in glucose-repressed cells. On the other hand the amounts of cytochromes $c$ and $a a_{3}$ were about fourfold less in the case of the latter.

Candida lipolytica grown on tetradecane showed changes in the cytochrome ratios depending on the phase of growth. Stationary phase cells were relatively rich in cytochromes $a a_{3}$ while exponential phase cells were extremely rich in cytochrome $b$ (Table 4 ).

Cytochrome ratios in the isolated mitochondria were again complicated by some loss of cytochrome $c$ during the isolation procedures. Nevertheless, the relatively high cytochrome $b$ 
Table 5. Percentage inhibition of mitochondrial ATPase by oligomycin at various $\mathrm{pH}$ values

\begin{tabular}{|c|c|c|c|c|}
\hline & & & $(\mu \mathrm{g} /$ & \\
\hline & $\mathrm{pH}$ & 2 & IO & 50 \\
\hline Saccharomyces & & & & \\
\hline Ethanol & $7 \cdot 0$ & II & 38 & 88 \\
\hline & $9 \cdot 5$ & 57 & 86 & 95 \\
\hline Candida lipolyt & & & & \\
\hline Ethanol & $7 \cdot 0$ & 36 & 66 & 74 \\
\hline & $9 \cdot 5$ & 28 & 44 & 47 \\
\hline Tetradecane & $7 \cdot 0$ & 45 & $8 I$ & 82 \\
\hline & $9 \cdot 5$ & 38 & 58 & 62 \\
\hline
\end{tabular}

and $a a_{3}$ content of the $C$. lipolytica mitochondria as compared with those of $S$. cerevisiae was still evident. This was true also for mitochondria isolated from both ethanol- and tetradecane-grown cells.

\section{Mitochondrial ATPase}

The $\mathrm{pH}$ profiles of the mitochondrial ATPase of $C$. lipolytica and $S$. cerevisiae have been described in a previous paper (Houghton et al. 1973). The specific activity of the $C$. lipolytica enzyme was never greater than $\mathrm{I} \cdot 0 \mu \mathrm{mol} / \mathrm{min} / \mathrm{mg}$ protein and, although comparable with that of $S$. cerevisiae in the $\mathrm{pH}$ range 6.0 to $7 \cdot 0$, it was much lower in the $\mathrm{pH}$ range 8.0 to I0.0 where the specific activity of the $S$. cerevisiae ATPase was 4.0 to $5.0 \mu \mathrm{mol} / \mathrm{min} / \mathrm{mg}$ protein. The $\mathrm{pH}$ profile and specific activities of the ATPase of $S$. cerevisiae mitochondria were in good agreement with those of Kovac et al. (1968). The effect of varying the $\mathrm{Mg}^{2+}$ : ATP ratio at $\mathrm{pH}$ values 7.0 and 9.5 on the mitochondrial ATPase activities of $C$. lipolytica and $S$. cerevisiae cells grown on ethanol was examined. Both $S$. cerevisiae and C. lipolytica showed optimal ATPase activity at $\mathrm{Mg}^{2+}:$ ATP ratios of $\mathrm{I}: \mathrm{I}$ and $\mathrm{I}: 2$ at $\mathrm{pH}$ values 7.0 and 9.5 respectively. In $S$. cerevisiae the specific activity at $\mathrm{pH} 9.5$ was still 3 to 4 times that at $\mathrm{pH} 7 \cdot 0$, even when both were assayed at their respective optimal $\mathrm{Mg}^{2+}$ : ATP ratios. Conversely, for $C$. lipolytica the specific activities at $\mathrm{pH} 7.0$ and $\mathrm{pH} 9.5$, again at their optimal $\mathrm{Mg}^{2+}$ :ATP ratios, were approximately the same.

Mitochondrial ATPase is characteristically inhibited by oligomycin in both mammalian and yeast mitochondria except that rather higher concentrations of oligomycin are required for comparable levels of inhibition of yeast ATPase. As shown previously (Houghton et al. I973) S. cerevisiae ATPase was more resistant to inhibition by oligomycin when the activity was assayed at $\mathrm{pH} 7.0$ than at $\mathrm{pH} 9.5$ (Table 5). A completely opposite situation was found in C. lipolytica mitochondrial ATPase. Low concentrations of oligomycin in the range of ro $\mu \mathrm{g} / \mathrm{mg}$ protein gave only $40 \%$ inhibition at $\mathrm{pH} 9.5$ against 80 to $90 \%$ for the $S$. cerevisiae activity. The picture was reversed at $\mathrm{pH}_{7.0}$ in that the $C$. lipolytica ATPase was inhibited to 60 to $70 \%$ but that of $S$. cerevisiae to about $40 \%$. Moreover, the inhibition of the C. lipolytica enzyme reached a plateau at high oligomycin concentrations (around $25 \mu \mathrm{g} /$ mg protein) in both the $\mathrm{pH} 7.0$ and 9.5 activities. The use of the $\mathrm{F}_{1}$ inhibitor of Pullman \& Monroy (1963) confirmed that the ATPase activities in the purified preparations from $S$. cerevisiae and $C$. lipolytica were essentially mitochondrial. In both, 70 to $80 \%$ of the ATPase activities were inhibited by $\mathrm{I} 50 \mu \mathrm{g} \mathrm{F}_{1}$ inhibitor $/ \mathrm{mg}$ protein at $\mathrm{pH} 7.0$. The ATPase in $C$. lipolytica mitochondria isolated from cells grown on tetradecane was slightly more 
sensitive to inhibition by oligomycin, at $\mathrm{pH} 7.0$ and $\mathrm{pH} 9.5$, than that in mitochondria obtained from ethanol-grown cells. Oligomycin at a concentration of $10 \mu \mathrm{g} / \mathrm{mg}$ protein gave $80 \%$ and $60 \%$ inhibition respectively at $\mathrm{pH} 7.0$ and $\mathrm{pH} 9.5$ (Table 5 ).

\section{DISCUSSION}

The growth of $C$. lipolytica on even-numbered hydrocarbons $\left(\mathrm{C}_{10}\right.$ to $\left.\mathrm{C}_{16}\right)$ resulted in cells containing over $95 \%$ of even-numbered fatty acids, predominantly $C_{18: 1}$ and $C_{18: 2}$. These results indicate chain elongation and desaturation of fatty acids. The fatty acids presumably arose from hydrocarbon oxidation, which has been suggested to be via the primary alcohol and then by dehydrogenation to the corresponding acid (Klug \& Markovetz, 1970).

The presence of high amounts of even-numbered fatty acids in $C$. lipolytica cells grown on odd-numbered hydrocarbons, particularly $\mathrm{C}_{11}$ and $\mathrm{C}_{13}$ (Table $\mathrm{I}$ ), indicated de novo synthesis and hence a possible cell requirement for even-chain fatty acids. On the other hand, growth in $\mathrm{C}_{15}$ hydrocarbon gave cells with about $20 \%$ of even-chain fatty acids and over $70 \%$ of the unusual fatty acid, $\mathrm{C}_{17: 1}$.

A predominance of cell fatty acid corresponding in chain length to the alkane substrate utilized has recently been reported in Candida tropicalis by Hug \& Fiechter (1973). These results differed from our observations, in which a predominance of cell fatty acid of longer chain length than the alkane substrate used was observed. In the present studies the cells were harvested at the end of exponential phase or early stationary phase and a lower substrate concentration was used $(0.1$ to $0.4 \%, v / v)$ than in the experiments of Hug \& Fiechter (I973) (I \%,v/v). It would appear, therefore, that the early steps of hydrocarbon utilization and fatty-acid synthesis were studied by Hug \& Fiechter (I973).

We have emphasized that the major fatty acids of Candida, namely $\mathrm{C}_{18: 1}$ and $\mathrm{C}_{18: 2}$, were different from those characteristic of Saccharomyces, $C_{16: 1}$ and $C_{18: 1}$. These differences may be important in conferring the structural and functional properties on the cell membranes necessary to assimilate the lipophilic hydrocarbon substrates. It is noteworthy, in this respect, that electron micrographs of yeast cells utilizing hydrocarbons have shown extensive invaginations of the plasma membrane (Ludvik, Munk \& Dostalek, 1968).

The mitochondrial membrane-bound enzymes (NADH oxidase, succinate oxidase and succinate dehydrogenase) of $C$. lipolytica cells grown on ethanol showed significantly higher specific activities and lower transition temperatures when compared with the corresponding enzymes of $S$. cerevisiae (Table 3). The differences in specific activities of the respiratorychain enzymes were supported by analysis of cytochrome spectra, which showed relatively high concentrations of cytochromes, particularly cytochromes $a a_{3}$ and $b$, in the Candida cells and mitochondria (Table 4). The lower transition temperatures observed for the respiratory-chain enzymes of ethanol-grown Candida cells is readily explicable in view of the recent work on the membranes of Mycoplasma laidlawii (Steim et al. 1969; Engelman, I97I; McElhaney, De Gier \& van der Neut-Kok, I973) and Escherichia coli (Wilson, Rose \& Fox, 1970; Overath, Schairer \& Stoffel, 1970; Esfahani et al. 1971). These studies have shown that breaks in Arrhenius plots of membrane-associated enzyme activity may be correlated with the degree of unsaturation of the membrane lipids: the greater the degree of unsaturation, the lower the transition temperature. A similar phenomenon has been reported in mitochondria isolated from aerobic and anaerobic cells of $S$. cerevisiae (Ainsworth et al. 1972; Watson et al. 1973a). More recent studies in this laboratory on a fattyacid auxotroph of $S$. cerevisiae have further shown a close correlation between specific activities, as well as transition temperatures, of mitochondrial membrane-bound enzymes 
and the degree of unsaturation of the membrane lipids (K. Watson, R. L. Houghton, E. Bertoli and D. E. Griffiths, unpublished).

A complicated picture was seen in a comparison of the mitochondrial ATPase of $C$. lipolytica and $S$. cerevisiae. The major observations were the much lower specific activity of the Candida ATPase and marked differences in $\mathrm{pH}$ profile and sensitivity to oligomycin. These observations may be an expression of distinct lipid-protein interactions within the mitochondrial membranes. It has been long established that phospholipids play a key part in the proper functioning of mitochondrial respiratory enzymes (Fleischer, Brierley, Klouwen \& Slautterback, I962; Green \& Tzagoloff, 1966) and mitochondrial ATPase (Kagawa \& Racker, 1966). More recent reconstitution studies have confirmed that phospholipids have a profound effect not only on the mitochondrial ATPase (Pitotti, Contessa, Dabenni-Sala \& Bruni, 1972; Swanljung, Frigeri, Ohlson \& Ernster, 1973) but also on the microsomal $\left(\mathrm{Na}^{+}-\mathrm{K}^{+}\right)$-ATPase activity (Taniguchi \& Iida, I972; Stahl, 1973).

The ability to manipulate the lipid composition of $C$. lipolytica and $S$. cerevisiae allows the design of experiments to investigate possible relationships between membrane lipid composition and enzyme activity. The incorporation of fatty acids not normally found in mitochondria, e.g. $\mathrm{C}_{17: 1}$, by growth of $C$. lipolytica on odd-numbered $n$-alkanes, is thus of interest.

This work was supported by grants from the Science Research Council. M.D.S. was a recipient of a C.A.P.S. award from the S.R.C. and British Petroleum Co. Ltd.

\section{REFERENCES}

Ainsworth, P. J., Tustanofr, E. R. \& Ball, A. J. S. (1972). Membrane phase transitions as a diagnostic tool for studying mitochondriogenesis. Biochemical and Biophysical Research Communications 47, I 299-1 305.

Engelman, D. M. (197I). Lipid bilayer structure in the membrane of Mycoplasma laidlawii. Journal of Molecular Biology 58, 153-165.

Esfahani, M., Limbrick, A. R., Knutton, S., OKA, T. \& Wakil, S. J. (1971). The molecular organization of lipids in the membrane of Escherichia coli: phase transitions. Proceedings of the National Academy of Sciences of the United States of America 68, 3180-3184.

Fleischer, S., Brierley, G., Klouwen, H. \& SlautTerback, D. B. (1962). Studies on the electron transfer system. XLVII. The role of phospholipids in electron transfer. Journal of Biological Chemistry 237, 3264-3272.

Gallo, M., Bertrand, J. C., Roche, B. \& Azoulay, E. (1973b). Cinétique de degradation des hydrocarbons par Candida tropicalis. Biochimica et biophysica acta 296, 624-638.

Gallo, M., Roche, B., Aubert, L. \& Azoulay, E. (1973a). Distribution des enzymes et des cytochromes de Candida tropicalis. Biochimie 55, 195-203.

VAN GeldeR, B. F. (1966). The extinction coefficient of cytochrome $a$ and cytochrome $a_{3}$. Biochimica et biophysica acta II8, 36-46.

Goma, G., Pareilleux, A. \&DURAND, G. (1973). Kinetics of hydrocarbon assimilation by Candida lipolytica. Archiv für Mikrobiologie 88, 97-I09.

Green, D. E. \& TZAGoloff, A. (I966). The role of lipids in the structure and function of biological membranes. Journal of Lipid Research 7, 587-602.

Houghton, R. L., Skipton, M. D., Watson, K. \& Griffiths, D. E. (1973). Comparative studies on the mitochondria of Saccharomyces cerevisiae and a hydrocarbon utilising yeast, Candida lipolytica. II. Mitochondrial ATPase. Transactions of the Biochemical Society I, I I IO-I I 3.

Hug, H. \& FIECHTER, A. (1973). Assimilation of aliphatic hydrocarbons by Candida tropicalis. Archiv für Mikrobiologie 88, 87-96.

Jayaraman, J., Cotman, C., Mahler, H. R. \& Sharp, C. W. (1966). Biochemical correlates of respiratory deficiency. VII. Glucose repression. Archives of Biochemistry and Biophysics 116, 224-25I. 
KAGAWA, Y. \& RACKER, E. (I966). Partial resolution of the enzymes catalysing oxidative phosphorylation. IX. Reconstitution of oligomycin-sensitive adenosine triphosphatase. Journal of Biological Chemistry 241, 2467-2474.

KING, T. E. \& HowARD, R. L. (1967). Preparation and properties of soluble NADH dehydrogenase from cardiac muscle. Methods in Enzymology Io, 275-294.

KLug, M. J. \& MARKovetz, A. J. (1970). Utilization of aliphatic hydrocarbons by microorganisms. Advances in Microbial Physiology 5, I-43.

Kovac, L., Bednarova, H. \& Greksak, M. (I968). Oxidative phosphorylation in yeast. I. Isolation and properties of phosphorylating mitochondria from stationary phase cells. Biochimica et biophysica acta I53, 32-42.

Lowry, O. H., Rosebrough, N. J., Farr, A. L. \& Randall, R. J. (195I). Protein estimation with the Folin phenol reagent. Journal of Biological Chemistry 193, 265-275.

Ludvik, J., Munk, V. \& Dostalek, M. (1968). Ultrastructural changes in the yeast Candida lipolytica by penetration of hydrocarbon into the cell. Experientia 24, 1066-1068.

MACKLER, B. \& HAYNES, B. (1973). Studies on oxidative phosphorylation in Saccharomyces cerevisiae and Saccharomyces carlsbergensis. Biochimica et biophysica acta 292, 88-91.

MCAuliffe, C. (I969). Solubility in water of normal $C_{9}$ and $C_{10}$ alkane hydrocarbons. Science, New York I63, $478-479$.

McElhaney, R. N., De Gier, J. \& van der Neut-Kok, E. C. M. (1973). The effects of alterations in fatty acid composition and cholosterol content on the nonelectrolyte permeability of Acholeplasma laidlawii $\mathbf{B}$ cells and derived liposomes. Biochimica et biophysica acta 298, 500-5I 2.

Moo-Young, M., Shimizu, T. \& Whitworth, D. T. (1971). Hydrocarbon fermentations using Candida lipolytica. I. Basic growth parameters for batch and continuous culture conditions. Biotechnology and Bioengineering 13, 74I-760.

Ohnishi, T., Heldt, H., Kroger, A., Pfaff, E. \& Klingenberg, M. (1967). The response of the respiratory chain and adenine nucleotide system to oxidative phosphorylation in yeast mitochondria. European Journal of Biochemistry I, 30I-3I I.

Overath, P., Schairer, H. U. \& Stoffel, W. (1970). The correlation in vivo and in vitro phase transitions of the membrane lipids in Escherichia coli. Proceedings of the National Academy of Sciences of the United States of America 67, 606-6r2.

Pitotti, A., Contessa, A. R., Dabenni-Sala, F. \& Bruni, A. (1972). Activation by phospholipids of particulate mitochondrial ATPase from rat-liver. Biochimica et biophysica acta 274, 528-535.

Pullman, M.E. \& MonRoy, G. C. (1963). A naturally occurring inhibitor of mitochondrial adenosine triphosphatase. Journal of Biological Chemistry 238, 3762-3769.

Skipton, M. D., Watson, K., Houghton, R. L. \& Griffiths, D. E. (I973). Comparative studies on the mitochondria of Saccharomyces cerevisiae and a hydrocarbon utilising yeast, Candida lipolytica. I. Unsaturated fatty acid and cytochrome composition. Transactions of the Biochemical Society I, I 107IIO9.

SLONImSKI, P. (1953). La formation des enzymes respiratoires chez la levure. Actualités biochemiques No. 17. Paris: Maisson et Cie.

STAHL, W. (1973). Role of phospholipids in the $\mathrm{Na}^{+}-\mathrm{K}^{+}$-stimulated adenosine triphosphatase system of brain microsomes. Archives of Biochemistry and Biophysics 154, 56-67.

Steim, J. M., Tourtellotte, M. E., Reinert, J. C., McElhaney, R. N. \& Rader, R. L. (I969). Calorimetric evidence for the liquid-crystalline state of lipids in a biomembrane. Proceedings of the National Academy of Sciences of the United States of America 63, 104-109.

Swanljung, P., Frigeri, L., Ohlson, K. \& Ernster, L. (I973). Studies on the activation of purified ATPase by phospholipids. Biochimica et biophysica acta 305, 519-533.

TANIGUCHI, K. \& IIDA, S. (1972). The effect of phospholipids on the apparent activation energy of $\left(\mathrm{Na}^{+}-\mathrm{K}^{+}\right)$ ATPase. Biochimica et biophysica acta 274, 536-54I.

Watson, K., Bertoli, E. \& Griffiths, D. E. (1973a). Phase transitions in yeast mitochondrial membranes. The transition temperatures of succinate dehydrogenase and $F_{1}$-ATPase in mitochondria from aerobic and anaerobic cells. FEBS Letters 30, I20-124.

Watson, K., Bertoli,'E. \& Griffiths, D. E. (1973b). Phase transitions in yeast mitochondrial membranes. In Abstracts 9th International Congress of Biochemistry, Stockholm, p. 272.

Watson, K., Haslam, J. M. \& Linnane, A. W. (1970). Biogenesis of mitochondria. XIII. The isolation of mitochondrial structures from anaerobically grown Saccharomyces cerevisiae. Journal of Cell Biology 46, 88-96. 
WickerhaM, L. J.(I946). A critical evaluation of the nitrogen assimilation tests commonly used in the classification of yeasts. Journal of Bacteriology 52, 293-30I.

Wilkinson, J.'F. (1971). In Microbes and Biological Productivity, pp. 15-46. Edited by D. E. Hughes and A. H. Rose. Cambridge: Cambridge University Press.

WILSON, D."\& EPEL, D. (1968). The cytochrome system of sea urchin sperm. Archives of Biochemistry and Biophysics 126, 83-90.

Wilson, G., Rose, A. \& Fox, G. F. (1970). The effect of membrane lipid unsaturation on glycoside transport. Biochemical and Biophysical Research Communications 38, 617-623. 